Jurnal Terapan Manajemen dan Bisnis is licensed under

A Creative Commons Attribution-Non_Commercial 4.0 International License.

\title{
HANDICRAFTS MAKE DECORATIVE LAMPS FROM PLASTIC SPOONS AS A CREATIVITY EFFORT STKIP SINGKAWANG STUDENTS
}

\author{
Zulfahita ${ }^{1)}$, Sri Novi ${ }^{2)}$, Nur Aisyah ${ }^{3)}$, Gita ${ }^{4)}$, Nurul $^{\text {5) }}$ \\ 1) STKIP Singkawang, Singkawang, Indonesia \\ E-mail: zulfahita@yahoo.co.id \\ 2) STKIP Singkawang, Singkawang, Indonesia \\ E-mail: srinovi781@gmail.com
}

\begin{abstract}
Decorative lights are one of the room accessories that can beautify the house. In addition to making the atmosphere of the house more cheerful, decorative lights can also be a simple solution to decorating a room without having to pay a fortune. In the modern era like today, people are increasingly creative in creating home gardens so that they become more beautiful. In the midst of society, various kinds of lamps are circulating in demand. Here, the team created a new, unique and interesting innovation, namely a decorative lamp in the shape of a lotus flower, made from an arrangement of plastic spoons attached to a used jar. This necessary material is quite easy to find and we find a lot in the environment around us because it is often used as daily necessities. There are many important factors that must be considered in order to promote this business, including choosing the right location, a good marketing strategy and determining a price that is affordable for the community. The business analysis of the handicrafts of decorative lamps from used bottles and plastic spoons includes a SWOT analysis. The team did this strategy to sell handicrafts from used jars and plastic spoons by promoting it. the schedule for the implementation of this craft for 3 months. . The price offered is quite affordable, according to the price that has been circulating in the market with good quality. In addition to the uniqueness and quality of the products of the place is also influential on the business to be carried out, the place of business also supports the sales process.
\end{abstract}

Keywords: handicrafts; plastic spoons; used jars

\section{Introduction}

In this modern era, many people only spend money to buy products or accessories to complement secondary need human. Actually, there are many objects or even waste around us can be used to make various creative crafts or products, innovative and has an economical selling value. One of them is waste utilization plastic jars for the manufacture of decorative lighting products. Utilization of waste as material product as a form of support for many recycling programs intensified by the government and community organizations. other than that utilizing waste can increase and develop entrepreneurial creativity and reduce the impact of environmental pollution caused by the waste. An easy way to comply with the 
conference paper formatting requirements is to use this document as a template and simply type your text into it. This activity is useful for triggering an innovative creative spirit in creating various kinds of creations in accordance with their ideas, thus stimulating individuals in fostering an entrepreneurial spirit, in order to create creative, innovative and friendly businesses. environment. For people with creativity in their own regions, it will indirectly help consumers in meeting their fashion needs without having to rely on goods from outside the region, especially big cities. Developing the potential for handicrafts from waste in the surrounding area can create jobs for local residents, reduce the impact of environmental pollution, reduce environmental pollution, and reduce unemployment in the community. This decorative lighting business is expected to develop existing creativity and increase the entrepreneurial spirit, from here the team wants to open a permanent place of business in a market area that is crowded with people, with the aim of making people more familiar with the products they produce.

\section{Literature Review}

Development prospects of making decorative lamps from used jars and plastic spoons.

The prospect of developing various kinds of decorative lights is to increase student creativity and innovation. This business relies on ideas and creativity, where the author must always provide new and creative innovations with materials from used bottles and plastic spoons that people enjoy doing and of course at very affordable prices, because the author's target is housewives to teenagers. In addition, the authors package the product in a beautiful and attractive manner to attract more consumers so that the price and quality of the product must be considered. The author's products always follow the times, starting from the shape, model, and theme according to consumer needs, but we still vary the theme so that the resulting product is different and unique. Related to the term craft, Couto in sudita (2014: 156) states that craft is related to the diligent nature of the hand or skill. The use of used goods into valuable products will be able to develop students' creative thinking skills.

The use of used goods is an alternative choice of art craft products as a form of accuracy in capturing opportunities and sensitivity to the surrounding environment. Many second-hand items can be used as aesthetic products by the hands of a creative person. According to Putra in Nyoman (2019: 304), the advantages of plastic compared to other materials include strong, lightweight, flexible, rust resistant, not easily broken, easy to color, easy to shape, and good heat and electrical insulators. Therefore, plastic waste has many advantages if it can be used as recycled products. This handicraft made from used jars and plastic spoons is a new invasion that is environmentally friendly, because this craft makes use of used jars that are not used, and are created into a unique and beautiful decorative lamp with a shape like a lotus flower. In making this decorative lamp does not require a long time, in just 1 day this decorative lamp can be used.

\section{Business economic analysis}

Carrying out a new business we need to know the things or aspects that affect the business. These include the aspects of strengths, weaknesses, opportunities, and threats. By analyzing these things, it is hoped that the business will run smoothly and successfully. Here are a few things from each of the above aspects.

\section{Price}

The price offered is quite affordable, according to prices already on the market with good quality. The price of decorative lights is RP. 120.000, - very affordable for all people, especially for housewives. 


\section{Description of Business Location}

In addition to the uniqueness and quality of the product, the place also affects the business to be carried out, the place of business also supports the sales process. We chose the city center and market because of its strategic location which is the place where most of the people carry out their activities. Not only that, this place is also traversed by many vehicles so that the opportunity gap is very large.

Needs of raw materials and production equipment

Table 1. tools and materials

\begin{tabular}{|c|l|c|l|}
\hline NO & \multicolumn{1}{|c|}{ RAW MATERIAL } & NO & TOOL'S NAME \\
\hline 1 & Plastic spoon & 1 & Scissor \\
\hline 2 & Plastic Jars & 2 & Cutter \\
\hline 3 & Lamp & 3 & Screwdriver \\
\hline 4 & Power Cable & 4 & Glue Shot \\
\hline 5 & Place of lamp & & \\
\hline 6 & Fitting lampu & & \\
\hline 7 & Hot Glue Gun & & \\
\hline 8 & Plastic Grass & & \\
\hline 9 & Thick Plywood Board & & \\
\hline
\end{tabular}

\section{Labor Needs}

In this business, we need 2 male workers, because men know better about electronics and usually men are able to do heavy work.

Table 2. Production process

\begin{tabular}{|l|l|l|l|}
\hline $\begin{array}{l}\text { Production } \\
\text { stage }\end{array}$ & $\begin{array}{l}\text { Type of activity and } \\
\text { method of manufacture }\end{array}$ & $\begin{array}{l}\text { Tools and } \\
\text { Materials }\end{array}$ & $\begin{array}{l}\text { Methods } \\
\text { and K3 }\end{array}$ \\
\hline Containment & Clean plastic bottles and plastic spoons & Water & - \\
\hline Formation & $\begin{array}{l}\text { Cut the handle spoon, cut into pieces } \\
\text { top and bottom of the bottle }\end{array}$ & Scissors / cutter & $\begin{array}{l}\text { Cloth } \\
\text { gloves }\end{array}$ \\
\hline Assembly & $\begin{array}{l}\text { Attaching the tip of the spoon to the } \\
\text { bottle, installing cables and lamps to } \\
\text { the bottle, installing plastic grass that } \\
\text { is affixed with thick plywood }\end{array}$ & $\begin{array}{l}\text { Hot glue gun, } \\
\text { plastic spoon, } \\
\text { plastic bottles, } \\
\text { cables, } \\
\text { screwdrivers, } \\
\text { plastic grass, } \\
\text { plywood boards }\end{array}$ & - \\
\hline Finishing & Installation of lights, and path testing & $\begin{array}{l}\text { Lights, paper } \\
\text { carton, electric } \\
\text { testpen }\end{array}$ & - \\
\hline
\end{tabular}


Research Methods

Implementation Method

The method of implementing this program is as follows:

1. Inception

Prepare materials and tools that will be used in making this handicraft such as used jars, plastic spoons and others that are used or needed.

2. Manufacture

Clean plastic bottles and plastic spoons, cut the handle of the spoon, cut off the top and bottom of the bottle.

3. Assembly

Attaching the tip of the spoon to the bottle, installing cables and lamps to the bottle, installing plastic grass that is affixed with thick plywood.

4. Finishing

Installation of lights, and testing of electrical linesProses pembuatan lampu hias dari toples bekas dan sendok plastik

5. The process of making decorative lamps from used jars and plastic spoons

The implementation of the business program of making decorative lamps from used jars and plastic spoons requires diligence and creativity

6. $\quad$ Making Decorative Lights

a. raw material

The raw materials used are used jars and plastic spoons and other equipment, and need a little thought to make their shape

b. adjuvant

The auxiliary materials used are also easy to find, such as glue, light fittings, lamp holders, cutters, and power cables.

The steps are:

1) Take a plastic spoon and cut the handle perfectly using a kater

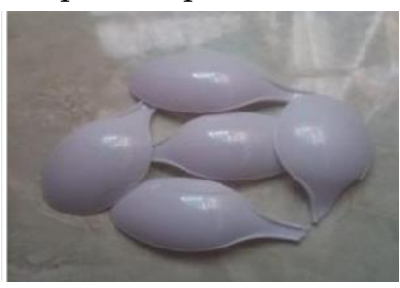

2) Take a jar of cut off the top.

3) Take the glue shoot then shoot the handle of the spoon a little bit with glue, then paste the spoon slowly the used jar.

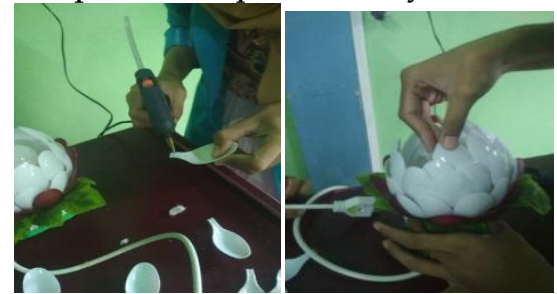

4) Attach the cable to the lamp place, then attach the light bulb. Then insert the lamp bulb that has been attached cable and place the lamp into the jar that has been decorated.

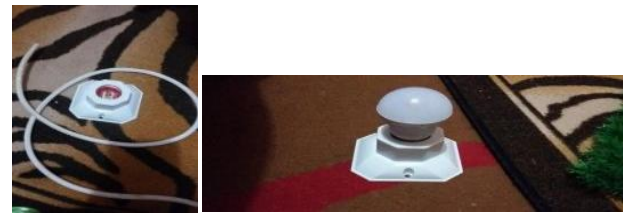


5) Take the plastic grass and attach it to the plywood board, then give nails in each corner to attach the plastic grass with the plywood board

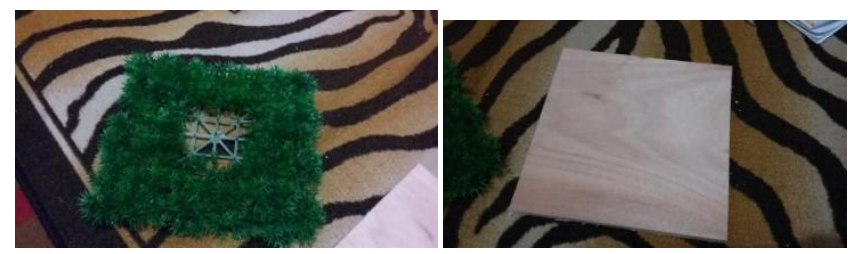

6) Then put the lamp decoration in the middle of the plastic grass..
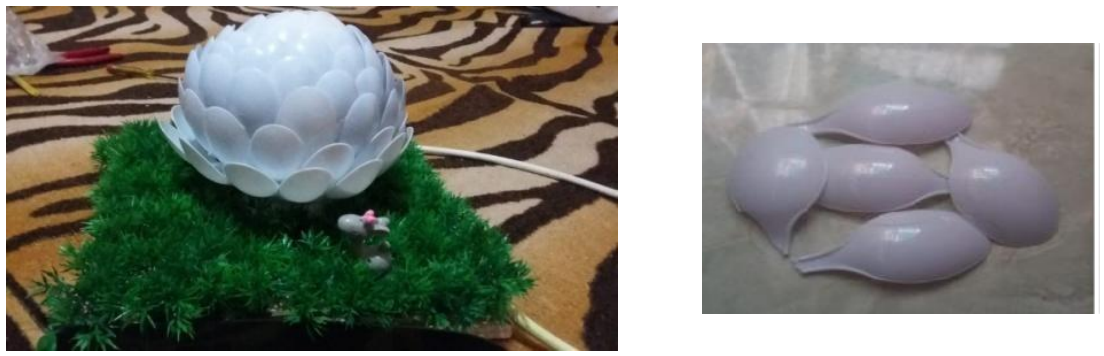

6) give accessories to your liking

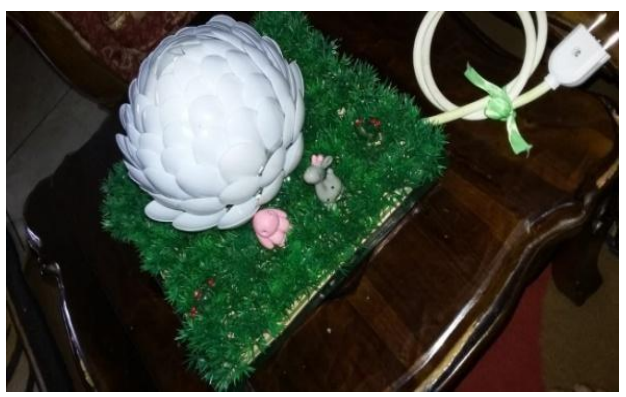

7. Business Strategy

a. Target market

The target market for selling decorative lamps from plastic spoons is the Singkawang city area. Especially the people of singkawang city and the residential environment around Singkawang.

b. Sales Strategy or market strategy

Strategy is an effort made by various parties to win the competition. According to Cravents in elsandra (2013:36) defines marketing strategy as analysis of development strategy and implementation of activities in target market determination strategy for products in each business unit, marketing goal setting, and development, Yesi Elsandra \& Ardhian Agung Yulianto, Marketing Strategy 37 implementation, as well as management of marketing program strategy, market positioning designed to meet the wishes of target market consumers. The strategy of selling various kinds of handicrafts from used jars and plastic spoons is done by promoting them. The effort that the team does is through the internet or social networks, so that not only close people know it but even distant people can know the team's efforts. 


\section{Results and Discussions}

\section{A. Budget}

Table 3. The funds used for the procurement of the following merchandise

\begin{tabular}{lll}
\hline № & Types of expenses & Cost ( Rp ) \\
\hline 1 & Default Cost & Rp 9.590.000 \\
2 & Production Cost & Idr 285,000 \\
3 & Other - other & Idr 345,000 \\
& Amount & Idr 10,220,000 \\
\hline
\end{tabular}

B. Schedule of activities

Table 4. schedule of PKM-K activities

\begin{tabular}{|c|c|c|c|c|c|c|c|c|c|c|c|c|c|c|}
\hline \multirow[t]{2}{*}{ № } & \multirow[t]{2}{*}{ Details of Activities } & \multicolumn{4}{|c|}{ September } & \multicolumn{5}{|c|}{ October } & \multicolumn{4}{|c|}{ November } \\
\hline & & 1 & 2 & 3 & 4 & 5 & 6 & 7 & 8 & 9 & 10 & 11 & 12 & 13 \\
\hline 1 & $\begin{array}{l}\text { Preparation Of } \\
\text { Manufacture } \\
\text { Business Proposal }\end{array}$ & & & & & & & & & & & & & \\
\hline 2 & $\begin{array}{l}\text { Business Location } \\
\text { Survey } \\
\text { And Raw Materials }\end{array}$ & & & & & & & & & & & & & \\
\hline 3 & $\begin{array}{l}\text { Material Procurement } \\
\text { Maid }\end{array}$ & & & & & & & & & & & & & \\
\hline 4 & $\begin{array}{l}\text { Media Procurement } \\
\text { Promotion }\end{array}$ & & & & & & & & & & & & & \\
\hline 5 & Running A Business & & & & & & & & & & & & & \\
\hline
\end{tabular}

In this modern era, many people only spend money to buy products or accessories to complement secondary need human beings. Actually, there are many objects or even waste around us can be used to make various creative crafts or products, innovative and have an economical selling value. This activity is useful to trigger innovative creative spirit in creating a variety of creations that are in accordance with their ideas, thereby stimulating individuals in fostering the entrepreneurial spirit, in order to create creative, innovative and environmentally friendly businesses. For people with creativity in their own areas, it will indirectly help consumers in meeting their fashion needs without having to rely on goods from outside the region, especially big cities. This decorative lamp business is expected to develop existing creativity and improve the entrepreneurial spirit, from here the team wants to open a permanent place of business in a market area that is crowded with the community, with the aim that the community knows the products produced better. Utilization of secondhand goods is an alternative choice of art handicraft products as a form of carefulness in capturing opportunities and sensitivity to the surrounding environment.

\section{CONCLUSION}

Many secondhand goods can be used as products of aesthetic value by the hands of someone creative. The material used is also easy to get ornamental lamps are made of used jars and also plastic spoons this material is often discarded and not utilized when in it will produce a prduk that is worth selling like this decorative lamp. The price offered is quite affordable, according to the price that has been circulating in the market with good quality. In addition to 
Jurnal Terapan Manajemen dan Bisnis

Volume 7 Number 1 March 2021. Page 81-87

e-ISSN: 2477-5282 p-ISSN: 2599-3127

the uniqueness and quality of the products of the place is also influential on the business to be carried out, the place of business also supports the sales process.

\section{References}

Humphrey, albert. Universitas Stanford. 1960. Analisis S W O T. fortune 500.

Anindita, Galih. Dkk. 2017. Pemanfaatan Limbah Plastik Dan Kain Perca Menjadi Kerajinan Tanagan Guna Meningkatkan Kualitas Sumber Daya Manusia. Surabaya: Politektik Perkapaalan Surabaya.

Sudita, ketut. 2014. Pemanfaatan Barang Bekas Sebagai Bahan Pembuatan Barong Mini Dalam Pembelajaran Seni Kerajinan Tangan. Singaraja: Universitas Pendidikan Ganesha. Jurnal Pendidikan dan Pengajaran, Jilid 47, Nomor 2-3, Oktober 2014, hlm.155-163. Diakses pukul 20:38.

Nyoman, I, Lokajaya. 2019. Pengolahan Limbah Plastik Menjadi Produk Kerajinan Tangan Untuk Meningkatkan Ekonomi Masyarakat Sendang Dajah. Surabaya: Universitas 17 Agustus 1945 Surabaya. Jurnal Abdikarya : Jurnal Karya Pengabdian Dosen dan Mahasiswa Oktober 2019 Vol 03 No 04, diakses pukul 22:01.

Elsandra,Yesi. dan Ardhian, Agung Yulianto. 2013. Strategi Pemasaran Untuk Meningkatkan Usaha Kecil Menengah Berbasis Industri Kreatif Melalui Ict. STIE Dharma Andalas. Jurnal Kajian Manajemen Bisnis, Volume 2, Nomor 1, Maret 2013, hlm 31-42. Diakses pukul 23:08. 